\title{
Aplikasi Hidrogel daripada Selulosa Bakteria (BC-g-PAA) sebagai Nanoreaktor bagi Menghasilkan Nanozarah Ferum Oksida (FeNps)
}

(A Novel Application of Bacterial Cellulose Hydrogel (BC-g-PAA) as a Nanoreactor to Produce Ferum Oxide Nanoparticle (FeNps))

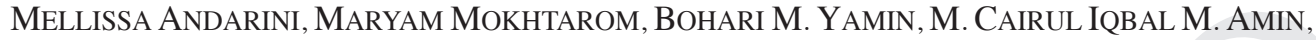 \\ IZZATI HASSAN \& AZWAN MAT LAZIM*
}

\begin{abstract}
ABSTRAK
Tujuan kajian ini adalah untuk mengkaji kebolehan hidrogel daripada selulosa bakteria (BC-g-PAA) sebagai pembawa bagi menghasilkan nanozarah ferum oksida (FeNps). Hidrogel selulosa telah disintesis menggunakan kaedah pempolimeran radikal bebas. Secara umum, kaedah pempolimeran radikal bebas ialah pempolimeran berantai (pempolimeran berion), dengan monomer radikal bebas menyerang monomer lain yang ikatannya berganda sehingga membentuk rantai dan akan melebarkannya. Nanozarah ferum oksida (FeNps) telah dihasilkan melalui gabungan antara $1 \times 10^{-4} \mathrm{~g} / \mathrm{mL} \mathrm{garam}$ ferosenium ke dalam sistem hidrogel, seterusnya agen penurun natrium oksida (NaOH) dengan kepekatan 1 M digunakan untuk mendapatkan zarah. Hidrogel di dalam larutan penimbal pada pH10 ialah yang mempunyai nisbah pembengkakan tertinggi. Keputusan FTIR menunjukkan bahawa asid akrilik (AA) berjaya dicangkukkan pada jaringan selulosa bakteria (SB). Imej hidrogel telah dicirikan melalui analisis mikroskopi elektron imbasan (SEM), diikuti oleh spektroskopi tenaga serakan X-ray (SEM-EDX) dalam penentuan peratusan elemen ferum $(\mathrm{Fe})$. Nanozarah berhasil diperolah selepas hidrogel dikalsinkan, seterusnya zarah tersebut diuji melalui mikroskopi transmisi elektron (TEM) dan pembelauan sinar-X (XRD). Analisis TEM menunjukkan diameter zarah berukuran 5 - $20 \mathrm{~nm}$. Keputusan XRD mengesahkan bahawa zarah yang diperoleh ialah ferum oksida $\left(\mathrm{Fe}_{3} \mathrm{O}_{4}\right)$ yang terletak pada puncak $2 \theta ; 32^{\circ}, 35^{\circ}, 49^{\circ}$ and $54^{\circ}$. Semua keputusan yang diperoleh menunjukkan bahawa hidrogel berasaskan selulosa bakteria berjaya digunakan sebagai nanoreaktor untuk menghasilkan nano zarah ferum oksida (FeNps).
\end{abstract}

Kata kunci: Ferosenium; hidrogel; nanoreaktor; selulosa bakteria (SB)

ABSTRACT

The aim of this study was to investigate the feasibility of bacterial cellulose hydrogel (BC-g-PAA) as a nanoreactor to produce ferum oxide nanoparticles (FeNps). The bacterial cellulose hydrogel was synthesized by using free radical polymerization method. In general, free radical polymerization method is a type of chain polymerization (like ionic polymerization), where free radical monomer attacks double bond of another monomer to form bond and propagate the free radical. Ferum oxide nanoparticles (FeNps) were produced by incorporating $1 \times 10^{-4} \mathrm{~g} / \mathrm{mL}$ ferrocenium salt $\left(\mathrm{Fe}^{+}\right.$ $\mathrm{Cl}^{-}$) into the hydrogel cellulose system and reduced using $1 \mathrm{M}$ concentration of sodium hydroxide (NaOH). The highest swelling ratio was observed at basic buffer solution ( $\mathrm{pH}$ H). The FTIR analysis was also conducted to confirm the grafting of acrylic acid (AA) onto bacteria cellulose backbone. Hydrogel was characterized by using scanning electron microscopy (SEM) followed by energy dispersive X-ray spectroscopy (SEM-EDEX) to determine the iron (Fe) percentage.The resulting nanoparticles were extracted from hydrogel after calcination process, further analysed by using transmission electron microscopy (TEM) and X-ray diffraction analysis (XRD). Analysis TEM showed the diameter of particles ranges from 5-20 $n m$.XRD examination confirmed that the ferum oxide particles $\left(\mathrm{Fe}_{3} \mathrm{O}_{4}\right)$ were located $2 \theta ; 32^{\circ}, 35^{\circ}, 49^{\circ}$ and $54^{\circ}$. The result demonstrate the feasibility of using bacterial cellulose hydrogel as promising as nanoreactor to produced ferum oxide nanoparticles (FeNps).

Keyword: Bacteria cellulose (BC); ferrocenium; hydrogel; nanoreactor

\section{PENDAHULUAN}

Ferum oksida bersaiz nano (FeNps) telah mendapatkan perhatian yang besar oleh para penyelidik kerana FeNps mempunyai peranan penting dalam bidang sains dan teknologi (Cornell \& Schwertmann 2003). Sebagai contoh, ferum oksida merupakan bahan penting dalam pembinaan peranti berasaskan magnet (Chertok et al. 2008; Raj \&
Mosovitz 1990), juga boleh sebagai mangkin bagi pelbagai tindak balas seperti, tindak balas Haber dalam penghasilan ammonia (Richardson \& Ponka 1995) dan tindak balas penghasilan gas hidrogen (Hua et al. 2004). Nanozarah berasaskan bahan tak organik daripada ion oksida, iaitu magnetit $\left(\mathrm{Fe}_{3} \mathrm{O}_{4}\right)$ dan maghemit $\left(\gamma-\mathrm{Fe}_{2} \mathrm{O}_{3}\right)$ yang disalutkan oleh polimer seperti dekstran (Hong et al. 2013), kitosan 
(Johari et al. 2012) dan poli(etilena glikol) merupakan pilihan utama kerana mudah disesuaikan terhadap bahan berasaskan bio (biokeserasian), bersifat super para magnetit dan memiliki sifat kimia yang seimbang (Yamin et al. 1996).

Kaedah yang telah digunakan bagi menghasilkan nano ferum oksida iaitu, teknik hidroterma (Chen et al. 1995), sol gel (Akbar et al. 2004), pirolisis secara semburan, enapan wap logam dan penyejatan secara laser (Kurland et al. 2009). Walaupun teknik ini menawarkan pendekatan yang baik, tetapi masih terdapat kelemahan dan hadnya. Kaedah pemendakan adalah kaedah yang selalu digunakan untuk menghasilkan nano ferum oksida. Namun begitu kelemahan kaedah ini adalah masalah penyebaran, kerana nanozarah mudah menggumpal (Yamin et al. 1996). Oleh yang demikian, kaedah alternatif diperlukan bagi menghasilkan produk yang lebih baik dan efisien.

Hidrogel adalah jaringan tiga dimensi dan ia boleh terbentuk daripada bahan polimer sintetik ataupun secara semula jadi seperti, selulosa, kitosan dan alginate (Chunyu et al. 2010). Kajian terdahulu menyatakan hidrogel mempunyai poros berukuran 50-100 nm dengan luas permukaan 300 and $400 \mathrm{~m}^{2} / \mathrm{g}$ (Murali et al. 2007). Hidrogel boleh dimanipulasi dengan mengikuti perubahan pada sekitarannya seperti $\mathrm{pH}$, kepekatan, suhu dan kekuatan ion (Hakam et al. 2015). Berasaskan bahan semula jadi, hidrogel selulosa ialah salah satu yang mendapat banyak perhatian oleh para penyelidik. Ini kerana sifatnya yang bioserasi kerana menyamai struktur tisu organisma (Sirajuddin et al. 2015) dan tidak toksik. Malah bahan asas untuk menghasilkan hidrogel jenis ini mudah diperoleh dan tidak mahal. Selain itu, ia mudah untuk dimanipulasi dengan menggabungkan polimer yang lebih responsif kerana ia mampu bertindak sebagai penyerap super (Johari et al. 2012). Lim et al. (2015) pula telah melaporkan hidrogel berasaskan sumber semula jadi amat sesuai dijadikan alternatif nanoreaktor bagi menghasilkan nanozarah.

Penggunaan hidrogel selulosa berasaskan NDC sebagai nanoreaktor bagi menghasilkan nanozarah ferum oksida (FeNps) daripada garam ferosenium masih belum dilaporkan oleh mana-mana penyelidik. Oleh itu, kajian ini telah menggunakan tindak balas pempolimeran radikal bebas untuk mensintesis hidrogel selulosa berasaskan NDC dengan asid akrilik (BC-g-PAA) bagi menghasilkan satu templat gel yang responsif seperti yang dilaporkan dalam kajian kumpulan kami yang terdahulu (Hakam et al. 2015; Liew et al. 2014). Seterusnya hidrogel ini telah dijadikan sebagai templat bagi penghasilan nanozarah seperti yang dicadangkan oleh Murali et al. (2007) dan larutan ferosenium pada kepekatan yang berbeza telah digabungkan dengan hidrogel BC-g-PAA. Templat hidrogel BC-g-PAAdan nanozarah FeNps daripada garam ferosenium kemudiannya dikaji dan dicirikan menggunakan instrumen analitikal seperti FTIR, SEM, EDX, TEM dan XRD. Hasil pengoptimuman daripada pencirian yang telah dijalankan penting bagi mencadangkan penggunaan hidrogel BC-g-PAA sebagai kaedah alternatif bagi menghasilkan FeNps.

\section{BAHAN DAN KAEDAH}

Nata de coco (NDC) diperoleh daripada pembekal makanan dalam bentuk kiub $\left(1 \times 1 \times 1 \mathrm{~cm}^{3}\right)$, untuk mendapatkan selulosa bakteria ( $\mathrm{SB})$. Ferosena $\left(\mathrm{Fe}\left(\mathrm{C}_{5} \mathrm{H}_{5}\right)_{2}\right)$, asid hidroklorik $(\mathrm{HCl})$, natrium hidroksida $(\mathrm{NaOH})$, asid akrilik (AA), $N, N$-metilenabisakrilamida (MBA), kalium peroksida sulfat (KPS) dan larutan penimbal, diperoleh daripada pembekal Sigma-Aldrich Ltd.

\section{PENYEDIAAN HIDROGEL SELULOSA DARIPADA SELULOSA BAKTERIA}

Dalam kajian ini hidrogel selulosa telah disediakan melalui kaedah pempolimeran bebas radikal seperti yang telah dilaporkan dalam kajian terdahulu (Hakam et al. 2015; Liew et al. 2014). Sebanyak 0.25 g kalium persulfate (KPS) yang telah dilarutkan dengan air suling (10 mL) dimasukkan ke dalam kelalang berleher tiga dan dipanaskan hingga mencecah kepada suhu $70^{\circ} \mathrm{C}$. Dalam masa yang sama, campurkan $1 \%$ larutan bakteria selulosa daripada nata de coco (NDC), asid akrilik (AA) dengan perbandingan (7:3) dan $N$ 'N-metilenabisakrilamida (MBA) sebanyak $0.04 \mathrm{~g}$ ke dalam bikar lalu dikacau tanpa sebarang haba hingga sebati. Setelah suhu kelalang mencapai $70^{\circ} \mathrm{C}$, larutan yang mengandungi campuran (NDC/AA/ MBA) dimasukkan ke dalam kelalang. Sampel kemudian dibiarkan selama 6 jam bagi membolehkan tindak balas berlaku lengkap. Selepas itu suhu dibiarkan menyejuk sehingga mencecah $60^{\circ} \mathrm{C}$ sebelum campuran dituangkan ke dalam piring petri. Sampel kemudiannya dikeringkan semalaman di dalam ketuhar pada suhu $40^{\circ} \mathrm{C}$.

\section{PENYEDIAAN GARAM FEROSENIUM}

Sebanyak $0.12 \mathrm{~g}\left(\mathrm{C}_{5} \mathrm{H}_{5}\right)_{2} \mathrm{Fe}$ (Ferosena) dilarutkan ke dalam $50 \mathrm{~mL}$ asid hidroklorik $(\mathrm{HCl})$, kemudian campuran tersebut dibiarkan selama satu minggu. Seterusnya, larutan berwarna biru dikacau selama 4 jam. Ini bertujuan untuk melarutkan semua hablur ferosena dalam lautan $\mathrm{HCl}$ (Bitterwolf et al. 1972; Hendrickson et al. 1971). Bagi kajian ini, larutan ferosena telah disediakan pada kepekatan yang berbeza namun, hanya kepekatan $1 \times 10^{-4} \mathrm{M}$ telah memberikan keputusan yang baik, maka kepekatan ini telah digunakan untuk kajian selanjutnya.

\section{PENGGABUNGAN FEROSENIUM DALAM SISTEM HIDROGEL SELULOSA}

Kaedah penyerapan telah digunakan dalam kajian ini bagi menggabungan ferosenium $(\mathrm{FeCl})$ dengan hidrogel selulosa seperti yang telah dilaporkan oleh Murali et al. (2010). Pertama, hidrogel BC-g-PAA direndam dalam larutan penimbal $(\mathrm{pH} 10)$ terlebih dahulu supaya ia membengkak. Seterusnya, ia kemudiannya dimasukkan ke dalam larutan ferosenium berkepekatan $1 \times 10^{-4} \mathrm{M}$ selama 3 hari. Langkah selanjutnya adalah dengan menambah $\mathrm{NaOH}$ (1 M). Setelah menambahkan $\mathrm{NaOH}$, warnanya hidrogel berubah daripada biru kepada jingga. 


\section{PROSES PENGKALSINAN \& PENGEMPARAN}

Bagi mendapatkan nanozarah tulen, langkah terakhir dalam kajian ini ialah proses pengkalsinan pada suhu $700^{\circ} \mathrm{C}$ selama satu jam. Proses ini bertujuan menghilangkan polimer hidrogel. Seterusnya, dilanjutkan dengan proses pengemparan dan pengemparan dilakukan dengan alat pengempar melalui putaran $200 \mathrm{rpm}$ selama satu jam sebanyak tiga kali. Hal ini dilakukan untuk membersihkan sisa-sisa polimer dan mendapatkan zarah yang tulen.

\section{INSTRUMENTASI}

\section{SPEKTROFOTOMETER INFRAMERA (FTIR)}

IR digunakan untuk membuktikan kehadiran kumpulan berfungsi dalam produk tindak balas yang telah dijalankan. Spektrum infra merah menunjukkan puncak kepada kumpulan berfungsi yang hadir dalam rantai polimer. FTIR ini direkodkan dengan menggunakan alat model Perkin Elmer Spektrum 400 FTIR yang mempunyai imbasan panjang gelombang diantara 650 hingga $4000 \mathrm{~cm}^{-1}$.

\section{ANALISIS PEMBENGKAKAN KO-POLIMER}

Analisis pembengkakan pada hidrogel menggunakan larutan penimbal pada $\mathrm{pH} 4,7$ dan 10 pada suhu bilik. Analisis ini dilakukan selama 48 jam untuk melihat penyerapan optimum hidrogel pada $\mathrm{pH}$ yang berbeza. Peratus pembengkakan mikrogel dan hidrogel boleh dikira melalui persamaan berikut:

$$
\text { peratus pembengkakan }(\%)=\frac{W s-W d}{W d} \times 100 \%
$$

dengan $W s$ adalah berat hidrogel setelah 48 jam pada $\mathrm{pH}$ yang berbeza; dan $W d$ adalah berat hidrogel yang telah dikeringkan (Varghese et al. 2008). Hasil peratus pembengkakan dilakukan minimal sebanyak tiga kali, untuk melihat hasil yang optimum.

MIKROSKOPI ELEKTRON IMBASAN (SEM) DAN SPEKTROSKOPI TENAGA SERAKAN X-RAY (SEM-EDX)

EDX yang digunakan melalui instrumen SEM model 1450 VP berjenama LEO. Data yang dihasilkan oleh SEM-EDX terdiri daripada spektrum unsur sebenar yang ada di dalam sampel hidrogel. Berikut beberapa contoh unsur yang selalu muncul pada setiap sampel, iaitu karbon (C), oksigen $(\mathrm{O})$, ferum $(\mathrm{Fe})$, nikel (Ni) dan magnesium $(\mathrm{Mg})$, bergantung kepada kandungan sampel tersebut.

\section{MIKROSKOPI TRANSMISI ELEKTRON (TEM)}

TEM bermodel Philips CM 12 berkuasa voltan $100 \mathrm{keV}$ digunakan untuk menganalisis sampel. Dalam penyediaan sampelnya, zarah ferum oksida terlebih dahulu dilarutkan ke dalam air ternyah ion seterusnya, diletakkan ke atas grid tembaga yang bersalut karbon dan dikeringkan dalam suhu bilik. Apabila zarah di atas grid telah kering maka sampel sedia untuk dianalisis.

\section{TEKNIK PEMBELAUAN SINAR-X (XRD)}

Ujian XRD telah dilakukan dengan menggunakan instrumen Model D8 advance yang berjenama Bruker dan dilakukan pada sudut yang bermula $3^{\circ}$ hingga $80^{\circ}$.

\section{KEPUTUSAN DAN PERBINCANGAN \\ MEKANISME PENGGABUNGAN HIDROGEL DENGAN FEROSENIUM ((BC-G-PAA)CL-)}

Hidrogel selulosa dimasukkan ke dalam $5 \mathrm{~mL}$ larutan ferosenium $(\mathrm{FeCl})$ yang bersifat asid. Seterusnya penambahan agen penurun $(\mathrm{NaOH})$ yang berkepekatan 1 M sebanyak $3 \mathrm{~mL}$, menyebabkan $\mathrm{pH}$ sekitarannya berubah menjadi alkali (pH12). Campuran antara BC-g-PAA dengan $\mathrm{FeCl}$ dibiarkan selama 72 jam. Terlihat jelas adanya perbezaan pada hidrogel sebelum dan selepas dimasukkan ke dalam larutan $\mathrm{FeCl}$, ilustrasi ditunjukkan pada Rajah 1 .

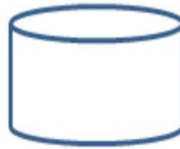

Hidrogel

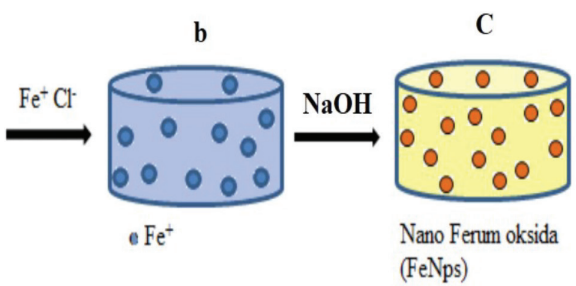

RAJAH 1. Skema kehadiran $\mathrm{Fe}^{+}$nanozarah di dalam jaringan hydrogel
SPEKTROSKOPI INFRAMERAH (FTIR) BC-G-PAA

Analisis FTIR menunjukkan ketiadaan puncak pada $1634 \mathrm{~cm}^{-1}$ pada sampel hidrogel selulosa menunjukkan terjadinya pempolimeran daripada kumpulan asid akrilik (AA) kepada poli asid akrilik (PAA) dengan terdapat puncak lainnya pada jalur $1707 \mathrm{~cm}^{-1}$ dijangkakan regangan bagi kumpulan karbonil $(\mathrm{C}=\mathrm{O})$ daripada PAA. Taut silang antara asid akrilik kepada bakteria selulosa dibantu oleh penaut silang (MBA) ditunjukkan dengan adanya kehadiran jalur baru pada $1022 \mathrm{~cm}^{-1}$ yang mewakili kumpulan C-O-C daripada sampel selulosa-g-PAA (Hakam et al. 2015; Liew et al. 2014).

\section{UJIAN PEMBENGKAKAN BC-G-PAA}

Perbezaan keupayaan pembengkakan hidrogel dalam medium pH berbeza dapat dilihat dengan jelas (Rajah 2). Rajah 2 menunjukkan peratus jerapan hidrogel BC-g-PAA melawan masa pada $\mathrm{pH}$ yang berbeza. Pembengkakan tertinggi berlaku pada hidrogel yang persekitarannya bersifat alkali (pH10). Larutan penimbal pada keadaan asid (pH4) menunjukkan hidrogel hanya mampu menjerap sebanyak 300\% larutan. Disini terlihat jelas bahawa pembengkakan mula berlaku apabila kumpulan asid karboksilik - $\mathrm{COOH}$ pada jaringan poli(asid akrilik) dinyah proton membentuk $\mathrm{COO}^{-}$bercas negatif kehadiran larutan. Kemudian, ketidakseimbangan tekanan osmosis 


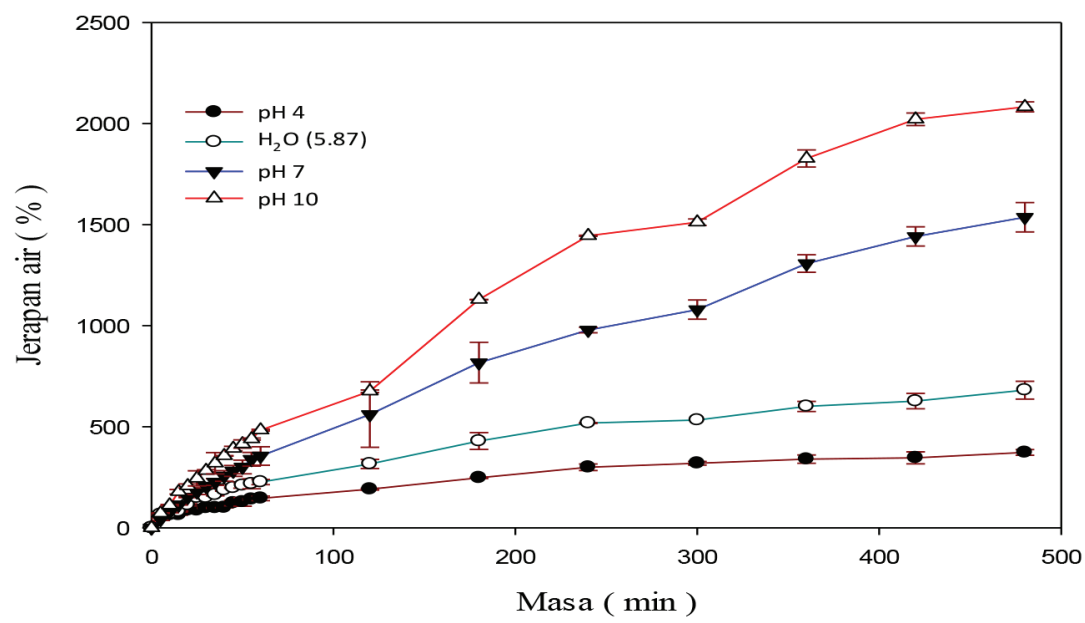

RAJAH 2. Jerapan air/larutan penimbal berbanding masa bagi sampel hidrogel BC-g-PAA

pada hidrogel dan medium persekitaran memaksa larutan terus menyerap ke dalam hidrogel hingga mencapai tahap keseimbangan. Namun dalam keadaan mesium berasid, pengembangan tidak dapat berlaku kerana penyeimbangan cas negatif kumpulan $\mathrm{COO}^{-}$dan cas positif pada $\mathrm{H}^{+}$oleh medium (Chunyu et al. 2010).

Perbezaan pembengkakan terhadap hidrogel yang telah digabungkan dengan larutan ferosenium turut dikaji (Rajah 3). Rajah 3(a) menunjukkan BC-g-PAA yang dimasukkan ke dalam larutan penimbal bersifat neutral (pH7) mempunyai pembengkakan $2000 \%$. Hal tersebut adalah kerana medium neutral bebas daripada rintangan sehingga membolehkan larutan masuk ke dalam jaringan hidrogel secara konsisten tanpa halangan dan proses tersebut berlaku hingga BC-g-PAA mencapai tahap tekanan osmosis yang seimbang (Liew et al. 2014).

Larutan ferosenium tanpa agen penurun adalah bersifat asid, pada keadaan ini tahap pembengkakan hidrogel rendah, dengan tahap maksimalnya hanya mencapai $400 \%$ (Rajah 3(b)), walau bagaimanapun, secara fizikal terdapat perubahan yang ketara pada hidrogel. Hidrogel BC-g-PAA

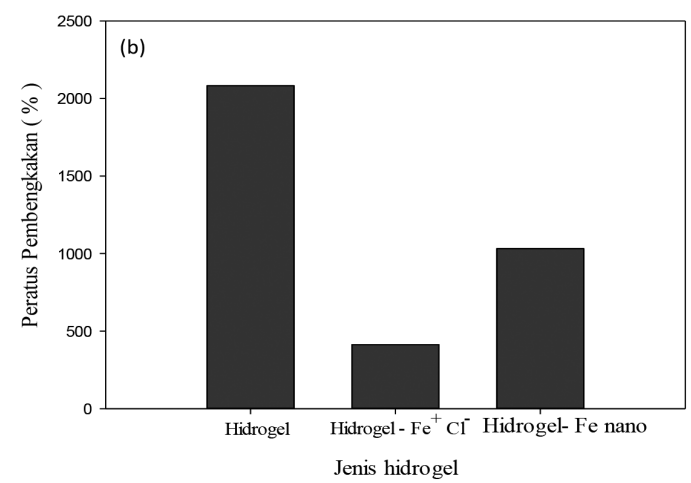

RAJAH 3. Peratus kebengkakan hidrogel bagi sampel, A: BC-gPAA di dalam larutan penimbal (pH7), B: $\mathrm{BC}^{-g}$-PAA di dalam $\mathrm{Fe}^{+}$ $\mathrm{Cl}^{-}$(asid) dan C: BC-g-PAA di dalam $\mathrm{Fe}^{+} \mathrm{Cl}^{-}$ditambah agen penurun $\mathrm{NaOH}$ (alkali) yang asalnya berwarna putih berjaya menjerap larutan $\mathrm{FeCl}$ yang turut mengubah warnanya menjadi biru. Rajah 3(c), adalah gabungan hidrogel selulosa dengan larutan ferosenium ((BC-g-PAA) $\left.\mathrm{Cl}^{-}\right)$, seterusnya ditambahkan agen penurun $(\mathrm{NaOH})$. $\mathrm{BC}^{-}$-g-PAA $) \mathrm{Cl}^{-}$mengalami pembengkakan lebih tinggi (1000\%) berbanding sebelum penambahan $\mathrm{NaOH}$, ini dikerana adanya daya elektrostatik saling menolak dengan medium (Murali et al. 2007). Kumpulan asid karboksilik akan terion pada $\mathrm{pH}$ bersifat alkali, sehingga menyebabkan saling tolak antara atom $\mathrm{COO}^{-}$. Hal lain yang menarik pada sampel ialah hidrogel yang berwarna biru berubah lagi menjadi jingga.

\section{MIKROSKOPI ELEKTRON IMBASAN (SEM)}

Analisis SEM telah dilakukan bagi melihat morfologi sistem polimer BC-g-PAA. Rajah 4(a) menunjukkan morfologi bagi sampel hidrogel selulosa yang telah dikering beku. Terdapat liang yang besar pada permukaan hidrogel. Liang dijangkakan terbentuk kerana adanya daya elektrostatik saling menolak antara sistem BC-g-PAA dengan medium pendispersi $\left(\mathrm{H}_{2} \mathrm{O}\right)$ pada saat digabungkan (Cairul et al. 2012). Hidrogel selulosa di dalam larutan yang bersifat asid, didapati permukaannya tidak rata dan mempunyai liang yang kecil (Rajah 4(b)). Hal tersebut dijangkakan terdapat keseimbangan cas oleh medium, sehingga hanya sedikit interaksi saling menolak antara BC-g-PAA dengan medium. Imej (c) pada Rajah 4 adalah (BC-g-PAA) $\mathrm{Cl}^{-}$yang telah ditambahkan agen penurun $(\mathrm{NaOH})$, perubahan persekitaran sampel daripada asid menjadi alkali turut merubah liang BC-g-PAA menjadi lebih besar. Perbezaan besar liang hidrogel disebabkan adanya tolakan ionik antara gel dengan persekitarannya (larutan pada pH berbeza) (Hakam et al. 2015). Faktor tersebut menyebabkan kurangnya rintangan pengaliran air atau penyebaran kandungan lainnya ke dalam jaringan hidrogel, sekaligus membolehkan hidrogel menyerap lebih banyak air serta kandungan logam hingga mencapai tahap keseimbangan (Aber et al. 2014). 

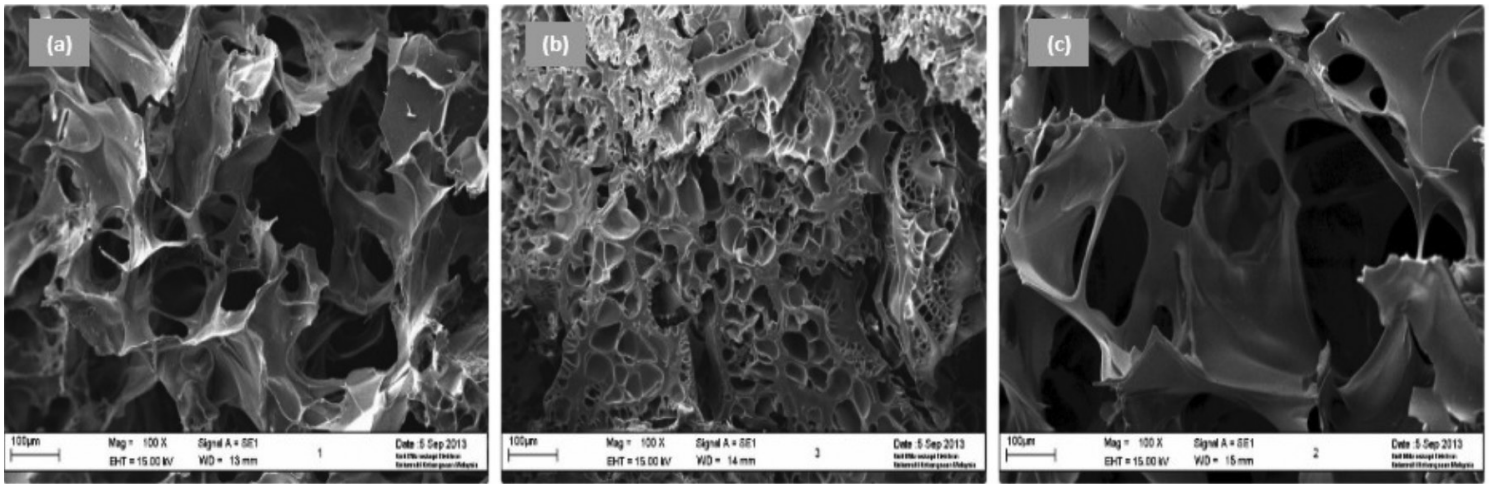

RAJAH 4. (a) Hidrogel BC-g-PAA, (b) hidrogel (BC-g-PAA)Cl- dan (c) setelah penambahan agen penurun $(\mathrm{NaOH})$ pada hidrogel $(\mathrm{BC}-\mathrm{g}-\mathrm{PAA}) \mathrm{Cl}^{-}$

SPEKTROSKOPI TENAGA SERAKAN X-RAY (EDX)

NANOZARAH SELEPAS PROSES PENGKALSINAN

Pengkalsinan telah dijalankan untuk menyingkirkan kumpulan hidroksil atau alkil. Proses ini telah dilakukan selama satu jam pada suhu $700^{\circ} \mathrm{C}$, bagi tujuan menyingkirkan polimer dan menghasilkan $\mathrm{Fe}_{3} \mathrm{O}_{4}$ (Murali et al. 2010). Hasil daripada proses pengkalsinan ini mendapati bahawa $100 \%$ polimer pada sampel telah hilang, ini ditunjukkan pada Rajah 5.

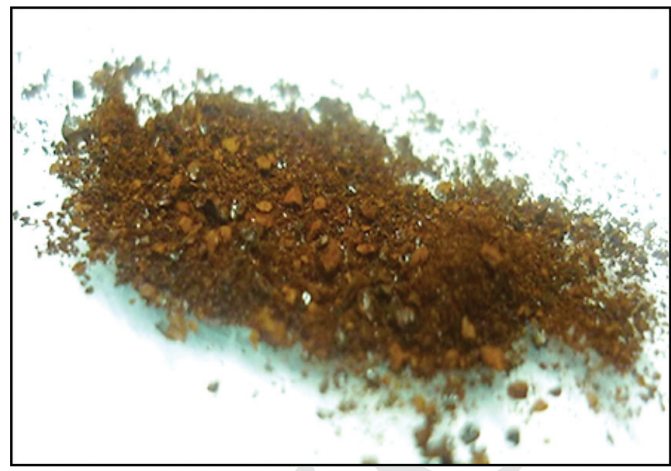

RAJAH 5. Zarah ferum oksida yang diperoleh daripada (BC-g-PAA) $\mathrm{Cl}^{-}$selepas pengkalsinan

Seterusnya, zarah yang diperoleh dianalisis menggunakan EDX. Spektra EDX (Rajah 6) menunjukkan adanya puncak bagi elemen ferum pada sampel sebanyak $2 \%$. Selain daripada ferum, terlihat puncak untuk elemen lainnya iaitu karbon $(\mathrm{C})$, oksigen $(\mathrm{O})$, natrium $(\mathrm{Na})$ dan klorida $(\mathrm{Cl})$. Puncak tertinggi didapati bagi elemen karbon, klorin dan natrium sedangkan puncak terendah ditunjukkan oleh elemen ferum, ini dijangkakan kerana pencucian pada sampel masih kurang bersih sehingga kadar garam $(\mathrm{NaCl})$ yang tinggi menutupi elemen ferum (Murali et al. 2007). Hal tersebut juga disokong oleh kajian Hong et al. (2013), kadar garam yang tinggi akan menyukaran instrumen untuk mengetahui elemen yang terkadung di dalam sampel kerana garam $(\mathrm{NaCl})$ menyelimuti elemen tersebut.

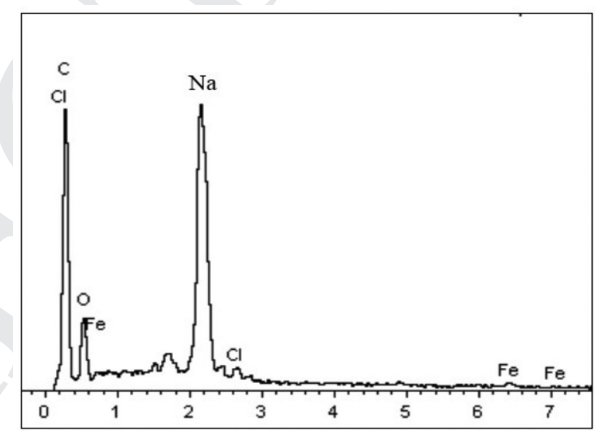

RAJAH 6. Spektoskopi tenaga serakan X-ray zarah daripada (BC-g-PAA)Cl- selepas pengkalsinan

MIKROSKOPI TRANSMISI ELEKTRON (TEM) NANOZARAH SELEPAS PROSES PENGKALSINAN

Nanozarah ferum oksida (FeNps) seterusnya dianalisis menggunakan instrumen TEM. Rajah 7 menunjukkan morfologi zarah berbentuk bulat dengan purata saiz sekitar $5.22 \mathrm{~nm}$. Imej dan ukuran zarah yang diperoleh daripada analisis TEM, dipastikan bahawa nanozarah ferum oksida (FeNps) telah berjaya dihasilkan. Walau bagaimanapun, imej tersebut menunjukkan serakan zarah yang tidak sekata dan mempunyai ukuran zarah yang berbeza namun begitu ukurannya masih kurang daripada $10 \mathrm{~nm}$.

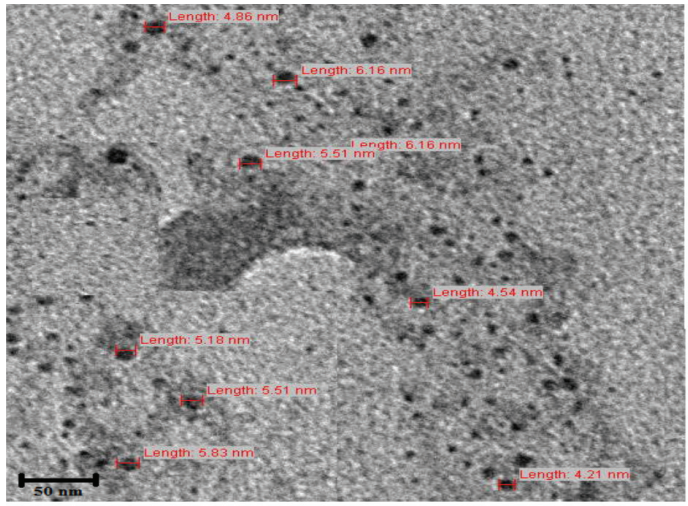

RAJAH 7. Morfologi dan saiz nanozarah ferum oksida oleh analisis TEM 
ANALISIS PEMBELAUAN SINAR-X (XRD) NANOZARAH SELEPAS PROSES PENGKALSINAN

Analisis pembelauan sinar- $X$ bertujuan untuk mengetahui kandungan suatu sampel. Difaktogram XRD bagi sampel hidrogel ditunjukkan dalam Rajah 8 dengan hidrogel dianalisis menggunakan instrumen XRD sebelum dan selepas pengkalsinan. Seperti yang dinyatakan oleh Murali et al. (2007), polimer hidrogel adalah bahan yang bersifat amorfus, oleh itu tiada sebarang puncak yang dapat dikesan melalui analisis XRD ini.

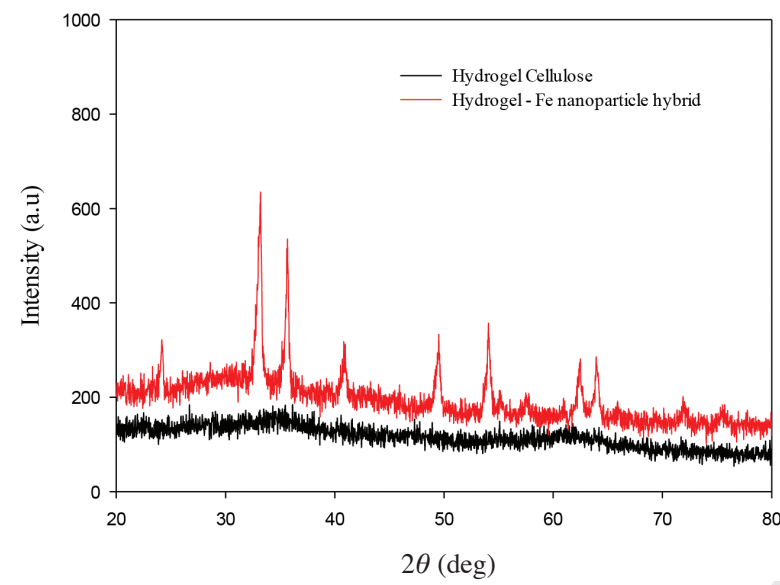

RAJAH 8. Difaktogram XRD bagi sampel (BC-g-PAA)Cl' sebelum dan selepas pengkalsinan

Keputusan menunjukkan zarah oren/jingga setelah polimer hidrogel dikalsinkan selama satu jam pada suhu $700^{\circ} \mathrm{C}$. Difaktogram XRD bagi zarah jingga/oren tersebut menunjukan beberapa puncak yang mewakili struktur magnetit, syn- $\mathrm{Fe}_{3} \mathrm{O}_{4}$ pada sudut $2 \theta ; 32^{\circ}, 35^{\circ}, 49^{\circ}$ and $54^{\circ}$ dan $54^{\circ}$. Kajian Hong et al. (2013), telah menyatakan analisis XRD dapat mengetahui sifat daripada ion yang terhasil berasaskan puncak yang terkesan oleh instrumen tersebut. Daripada hasil analisis XRD, dapat disimpulkan bahawa nano ferum oksida telah berjaya dihasilkan.

\section{KESIMPULAN}

Hidrogel selulosa berpotensi digunakan sebagai nanoreaktor untuk menghasilkan nanozarah ferum oksida. Sampel BCg-PAA telah berjaya menyerap larutan ferosenium ke dalam sistemnya, sama ada dalam keadaan asid ataupun alkali. Perubahan persekitaran larutan hidrogel daripada neutral kepada asid seterusnya alkali turut mempengaruhi warna BC-g-PAA, daripada putih menjadi biru jika persekitarannya asid dan berubah lagi menjadi jingga jika sekitarannya alkali.

Zarah yang telah diserap oleh polimer BC-g-PAA sukar untuk dikesan, oleh itu proses tambahan untuk mendapatkannya perlu dilakukan iaitu pengkalsinan. Proses pengkalsinan pada suhu $700^{\circ} \mathrm{C}$ telah dilakukan selama 1 jam dan berhasil menghilangkan polimer. Analisis
TEM menunjukkan zarah yang berwarna jingga tersebut mempunyai ukuran kurang daripada $20 \mathrm{~nm}$. Keputusan XRD membuktikan nanozarah bersifat ferum oksida bagi struktur magnetit, syn- $\mathrm{Fe}_{3} \mathrm{O}_{4}$

\section{PENGHARGAAN}

Penulis berterima kasih kepada Universiti Kebangsaan Malaysia (UKM) dan telah disokong oleh geran FRGS/1/2014/ ST01/UKM/03/1 dan GUP-2014-079.

\section{RUJUKAN}

Aber, M.M., Amin, M.C.I.M., Lazim, A.M., Pandey, M. \& Martin, C. 2014. Synthesis of a novel acrylated abietic acig-g-bacterial cellulose hydrogel by gamma irradiation. Carbohydrate Polymers 110: 505-512.

Akbar, S., Hasanain, S.K., Azmat, N. \& Nadeem, M. 2004. Synthesis of $\mathrm{Fe}_{2} \mathrm{O}_{3}$ nanoparticle by new sol-gel method and their structural and magnetic characterizations. Condensed Matter 480: 1-19.

Bitterwolf, T.E. \& Ling,A.C. 1972. Ring tilt and restricted rotation in protonated alkylferrocenes. Journal of Organometallic Chemistry 40: 197-203.

Cairul, M., Naveed, A., Halib, N. \& Ahmad, I. 2012. Syhnthesis and characterization of thermo and $\mathrm{pH}$ responsive bacterial cellulose/acrylic acid hydrogels for drug delivery. Carbohydrate for Drug Delivery 88: 465-473.

Chen, Q.W., Qian, Y.T., Chen, Z.Y., Xie, Y., Zhou, G.E. \& Zhang, Y.H. 1995. Hydrothermal deposition of magnetite $\mathrm{Fe}_{3} \mathrm{O}_{4}$ thin films. Materials Letter 24: 85-87.

Chertok, B., Moffat, B.A., David, A.E., Yu, F., Bergemann, C., Ross, B.D. \& Yang, V.C. 2008. Iron oxide nanoparticles as a drug delivery vehicle for MRI monitored magnetic targeting of brain tumors. Biomaterials 29: 487-496.

Chunyu, C., Bo, D., Jie, C. \& Lina, Z. 2010. Superabsorbent hydrogels based on cellulose for smart swelling and controllable delivery. European Polymer Journal 46: 92-100.

Cornell, R.M. \& Scwertmann, U. 2003.The Iron Oxide: Structure, Properties, Reaction, Occurences and Uses. Weinheim: Wiley-VCH Verlag GmbH \& Co. KGaA.

Hakam, A., Rahman, I.A., Jamil, M.S., Othaman, R., Amin, M.C.I. \& Lazim,A.M. 2015. Removal of methylene blue dye in aqueous solution by sorption on a bacterial-g-poly(acrylic acid) polymer network hydrogel. Sains Malaysiana 44(6): 827-834.

Hendrickson, D.N., Sohn, Y.S. \& Gray, H.B. 1971. Electronic structure of metallocenes. Journal of the America Chemical Society 93(15): 3603-3612.

Hua, J., Wei, K., Zheng, Q. \& Lin, X. 2004. Influence of calcination temperature on the surface and catalytic performance of Au/iron oxide for water shift-gas shift reaction. Applied catalyst 252: 121-130.

Hong, D., Snyder, J.F., Trans, D.T. \& Leadore, J.L. 2013. Hydrogel, aerogel and film of cellulose nanofibrils functionalized with silver nanoparticles. Carbohydrate Polymer 95: 760-767.

Johari, N.S., Ahmad, I. \& Halib, N. 2012. Comparison study of hydrogel properties synthesized with micro- and nano- size bacterial cellulose particles extracted from nata de coco. Chem. Biochem. Eng. 26(4): 399-404. 
Kurland, H.D., Grabow, J., Staupendahl, G., Müller, F.A., Müller, E., Dutz, S. \& Bellemann, M.E. 2009. Magnetic iron oxide nanopowders produced by $\mathrm{CO}_{2}$ evaporation - 'In situ' coating and particle embedding in a ceramic matrix. Journal of Magnetism and Magnetic Material 321(10): 1381-1385. Proceedings of the Seventh International Conference $n$ the Scientific and Clinical Applications of Magnetic Carriers, Vancouver, British Columbia, Canada. 20-24 May 2008.

Lim, S.L.,Ahmad, I. \& Lazim, A.M. 2015.pH sensitive hydrogel based on poly(acrylic acid) and cellulose nanocrystals. Sains Malaysiana 44(6): 779-785.

Liew, M., Othaman, R., Khalid, R.,Amin, M.C.I. \& Lazim, A.M. 2014. Sintesis hidrogel berasaskan nata de coco dengan asid akrilik sebagai ko-monomer menggunakan kaedah pempolimeran radikal bebas. Malaysian Journal of Analytical Science 18(2): 299-305.

Murali, Y.M., Vimala, K., Thomas, V., Varaprasad, K., Shredaar, B., Bajpai, S.K. \& Raju, K.M. 2010. Controlling of silver nanoparticle structure by hydrogel network. Journal of Colloid and Interface Science 342: 73-82.

Murali, Y.M., Kyungjae, L., Thathan, P. \& Kurt, E.G. 2007. Hydrogel networks as nanoreactors: A novel approach to silver nanoparticles for antibacterial application. Polymer 48: $158-164$

Raj, K. \& Moskovitz, K. 1990. Commercial applications of ferrofluids. Journal of Magnetism and Magnetic Materials 85: 233-245.

Richardson, D.R. \& Ponka, P. 1995. Identification of a mechanism of iron uptake by cells which is stimulated by hydroxyl radicals generated via the iron catalysed Haber-Weiss reaction. Molecular Cell Research 1269: 105-114.

Sirajuddin, N.A., Jamil, M.M.S. \& Lazim, A.M. 2015. Effect of pH buffer self-healing hydrogel. Malaysian Journal of Analytical Science 19(2): 445-453.
Varghese, J.M., Ismail,Y.A.,Chang, K.L., Kwang, M.S., Min,K.S., Sun, I.K., Insuk, S.S. \& Seon, J.K. 2008. Thermoresponsive hydrogels based on poly(N-isopropylacrylamide)/chondroitin sulfate. Sensors and Actuators B: Chemical 135: 336-341.

Yamin, B.M., Suwandi, S.A., Sivakumar, K. \& Shawkatly, O.B. 1996. A triclinic form of dipyrrolidylthiuram disulphide. Acta Crystal 52: 1966-1968.

Mellissa Andarini, Maryam Mokhtarom, Bohari M. Yamin,

Izzati Hassan \& Azwan Mat Lazim

Pusat Pengajian Sains Kimia dan Teknologi Makanan

Fakulti Sains dan Teknologi

Universiti Kebangsaan Malaysia

43600 UKM Bangi, Selangor Darul Ehsan

Malaysia

M. Cairul Iqbal M. Amin

Fakulti Farmasi, Universiti Kebangsaan Malaysia

Jalan Raja Muda Abdul Aziz

50300 Kuala Lumpur, Wilayah Persekutuan

Malaysia

*Pengarang untuk surat-menyurat; email: azwanlazim@ukm. edu.my

Diserahkan: 10 Jun 2017

Diterima: $\quad 21$ September 2017 